\title{
CELEBRACIÓN PÚBLICA, RITUALIDAD POLÍTICA Y CEREMONIAL RELIGIOSO: LA PUBLICACIÓN Y EL JURAMENTO DE LA CONSTITUCIÓN DE CÁDIZ EN EL SUROESTE PENINSULAR EN 1812*
}

\section{PUBLIC CELEBRATION, POLITICAL RITUALITY AND RELIGIOUS CEREMONIAL: THE PUBLICATION AND OATH OF THE CONSTITUTION OF CADIZ IN THE SOUTHWEST PENINSULAR IN 1812}

\author{
José Saldaña Fernández \\ Universidad de Sevilla
}

SUMARIO: I. INTRODUCCIÓN. PRÁCTICAS Y RELATOS DESDE LO LOCAL.- II. EL MARCO NORMATIVO Y SU PROYECCIÓN PÚBLICA Y SOCIAL.- III. RITUALIDAD FESTIVA, TIEMPO Y ESPACIO. LECTURAS DESDE LOS MÁRGENES.- 3.1. Entre el Guadiana y el Odiel.- 3.2. La Sierra de Aracena y Picos de Aroche.- 3.3. El Condado de Niebla.- IV. CONSIDERACIONES FINALES

Resumen: La Constitución de 1812 requirió desde un principio del conocimiento y la adhesión pública del conjunto de la población, circunstancias que las autoridades de Cádiz trataron de conseguir mediante una puesta en escena de carácter protocolario y festivo: a la publicación en lugar público y lectura en voz alta $\mathrm{y}$ al juramento en la parroquia se añadian repiques de campana, iluminaciones y salvas de artillería. Pero la realidad resultó finalmente mucho más rica y compleja, sobrepasándose en no pocos casos el marco de celebración recogido en la normativa. Precisamente, este artículo analiza el desarrollo de la publicación y el juramento constitucional en diversos pueblos del suroeste peninsular y permite constatar la pluralidad de experiencias como resultado de la combinación de directrices generales establecidas desde fuera de la comunidad y de las lecturas e interpretaciones que se hacian desde dentro de la misma a partir de sus realidades y tradiciones propias.

Abstract: The Constitution of 1812 required from the beginning the knowledge and public support of the population, what the Cadiz authorities tried to achieve through a formal and festive mise en scene: its publication and reading aloud in a public place, the oath in the parish church, accompanied by peal of bells, illuminations and artillery salvoes. But the reality was ultimately much richer and more complex, exceeding in not a few cases the framework of celebration included in the regulations. Precisely, this article analyzes the development of the publication and the constitutional oath in several towns in the southwest of the Iberian Peninsula and allows us to verify the plurality of experiences resulted from the combination of the general guidelines established from outside the

\footnotetext{
* Este trabajo se enmarca en el proyecto "La dimensión popular de la política en Europa meridional y América Latina, 1789-1898" (PID2019-105071GB-100), del Ministerio de Ciencia e Innovación.
} 
community and the readings and interpretationsmade from within influenced by its own realities and traditions.

Palabras clave: Constitución de 1812, Publicación, Juramento, Suroeste peninsular, Fernando VII

Key Words: Constitution of 1812, Publication, Constitutional oath, Southwest Iberian Peninsula, Ferdinand VII

\section{INTRODUCCIÓN. PRÁCTICAS Y RELATOS DESDE LO LOCAL}

La Guerra de la Independencia ha quedado caracterizada como el momento inaugural de la contemporaneidad en España, cuya trascendencia y proyección a lo largo del tiempo resultan perceptibles tanto desde el punto de vista público y social como historiográfico y académico. La cercana celebración de su bicentenario ha vuelto a dar cuenta de su aún persistente vitalidad, de tal manera que ha terminado generándose una numerosa bibliografia que, asumiendo diferentes perspectivas y escalas de análisis, ha permitido ampliar notablemente nuestro conocimiento sobre aquellos decisivos años.

Ahora bien, por encima de esas nuevas lecturas, algunos ámbitos todavía se prestan a nuevas miradas y matices. Por ejemplo, a pesar de la amplitud de perspectivas abiertas sobre cuestiones politicas, institucionales o sociales, y de los nuevos acercamientos que ello comportaba sobre ejes más concretos relacionados, entre otros, con la Iglesia, las Cortes de Cádiz o la Constitución de 1812, los espacios que median entre unos y otros aún presentan interesantes oportunidades y desafios. Dentro de estos puntos de encuentro cabrían situar los actos de publicación y juramento de la Constitución de Cádiz puestos en marcha de manera escalonada desde su promulgación, y donde confluían los nuevos conceptos y praxis en el campo de la politica abiertos desde 1808 con otras prácticas y ceremoniales festivos de larga proyección durante el Antiguo Régimen.

Esos momentos representan un buen marco de análisis porque, además de aunar diferentes dimensiones comunitarias -entre otras, desde la articulación del nuevo espacio de participación política a las concepciones simbólicas y lecturas específicas que ello comportaba-, permiten hacerlo considerando las circunstancias y las manifestaciones concretas en los diferentes pueblos y comarcas. En este sentido, desde hace algunas décadas se vienen publicando trabajos que muestran los diversos tiempos, ritmos y adaptaciones que se dieron en los diferentes territorios de la monarquía -tanto en España ${ }^{1}$ como en

\footnotetext{
1 Los trabajos sobre el desarrollo concreto de los actos de publicación y juramento de la Constitución de Cádiz en España, con algunos ejemplos de relevancia en las últimas décadas del siglo XX, tomarian no obstante un significativo impulso con el nuevo siglo y la celebración del bicentenario, en los cuales han primado además los enfoques locales y comarcales de resultados muy distintos: entre otros, Fernando Jiménez de Gregorio, Los pueblos de Toledo juran la Constitución de 1812, Diputación Provincial, Toledo, 1984; Fernando Jiménez de Gregorio, "La provincia de Madrid en la guerra de Independencia: sus pueblos juran la constitución de 1812", Anales del Instituto de Estudios Madrileños, $\mathrm{n}^{\circ}$ 26, 1996, pp. 625-642; Elvira López-Cuevillas, "Provisiones, proclamación y juras de la Constitución en 1812 y 1820 y quemas de la Constitución en 1814 y 1823 en los libros de actas del Ayuntamiento de Orense", Boletín auriense, $\mathrm{n}^{\circ} 24,1994$, pp. 227-252; Isabel Parra Jiménez, "Moraleja la Mayor jura la Constitución de 1812", Anales del Instituto de Estudios Históricos del Sur de Madrid "Jiménez de Gregorio", nº 5, 2005, pp. 101-110;
} 
América $^{2}-$, y en los que tendrian un especial protagonismo ciertas formas de representación de la realidad apegadas a relatos y prácticas tradicionales. No hay que perder de vista que en aquel contexto de crisis de la monarquía, con claras innovaciones en cuanto a los medios de comunicación y los sistemas de transmisión de los nuevos discursos, los rituales no perdieron sin embargo su significación a la hora de difundir ideas y relatos de poder ${ }^{3}$, de ahí las líneas de continuidad que pueden trazarse en las liturgias y celebraciones públicas de la segunda mitad del siglo XVIII y primeras décadas del XIX ${ }^{4}$. La implementación del

Emilio García Campra, "La jura de la Constitución de 1812 en Berja, Adra y Dalias”, Farua: revista del Centro Virgitano de Estudios Históricos, $\mathrm{n}^{\circ}$ 13, 2010, pp. 115-126; Luis Francisco Peñalver Ramos, "Talavera de la Reina y la Constitución de 1812. Tres momentos para recordar en el bicentenario de 'La Pepa", Alcalibe: Revista Centro Asociado a la UNED "Ciudad de la Cerámica", n" 11, 2011, pp. 112-128; Ana Isabel Arias Fernández, "La Constitución de 1812 en la ciudad de León", Argutorio: revista de la Asociación Cultural "Monte Irago", no 29, 2012, pp. 76-81; Antonio Giménez Azcona, "Proclamación y jura de la Constitución de 1812 en Espiel", Crónica de Córdoba y sus pueblos, $\mathrm{n}^{\circ}$ 18, 2012, pp. 257-264; Román Piña Homs, "El día en que Palma juró la Constitución de 1812", Memòries de la Reial Acadèmia Mallorquina d'Estudis Genealògics, Heràldics $i$ Històrics, $\mathrm{n}^{\circ}$ 22, 2012, pp. 187-197; Lorenzo Gómez Gómez, Año 1812, jura de la Constitución en los pueblos de la provincia de Ávila: Ávila, Adanero, El Arenal..., Lorama, San Martín de Valdeiglesias, 2012; Carmen Cascón Matas y Antonio Avilés Amat, "La Constitución de 1812 y Béjar", Revista de Estudios Bejaranos, $n^{\circ}$ 16, 2012, pp. 39-57; Eduardo Tejero Robledo y Inocencio Cadiñanos Bardeci, "Bicentenario de la Constitución de Cádiz (1812) y su jura en villas y pueblos del Tiétar", Trasierra: boletín de la Sociedad de Estudios del Valle del Tiétar, n 10, 2012-2013, pp. 17-50.

2 Algo parecido ha venido ocurriendo con los trabajos referidos al espacio americano, tanto por haber alcanzado un notable incremento en las últimas décadas bajo el impulso de la celebración del bicentenario, como por presentar asimismo marcadas diferencias geográficas y de enfoque, si bien con un predominio de acercamientos a partir de los diferentes marcos nacionales y con especial atención a las ciudades y enclaves principales de cada uno de ellos: por ejemplo, Jairo Gutiérrez Ramos, "La Constitución de Cádiz en la provincia de Pasto, virreinato de Nueva Granada, 1812-1822", Revista de Indias, vol. LXVIII, no 242, 2008, pp. 207-224; Jairo Gutiérrez Ramos, "La Constitución de Cádiz en las provincias caribeñas de la Nueva Granada", Historia Caribe, vol. VII, n 20, 2012, pp. 39-58; Armando Hernández Souvervielle, "La jura de la Constitución de Cádiz en San Luis Potosí (1813). Un discurso barroco del poder a través de la Iconología de Ripa", Fronteras de la Historia, vol. 16, n 1 , 2011, pp. 102-134; Abelardo Levaggi, "La Constitución española de 1812 e Hispanoamérica", Iushistoria, $\mathrm{n}^{\circ}$ 2, 2009, pp. 7-30; Daniel Morán, “¡Viva la Constitución! La prensa y la imagen de la constitución gaditana en el Perú, 1812-1814”, Historia Caribe, vol. VII, no 20, 2012, pp. 59-75; Edgar Soriano, "Una aproximación a las experiencias del juramento de la Constitución de Cádiz en el contexto de Tegucigalpa (1812-1820)", en Bicentenario de la Constitución de Cádiz en Honduras, AECID, Tegucigalpa, 2012, pp. 89-106; F. Javier Campos y Fernández de Sevilla, "La Constitución española de 1812 y su recepción en Perú", e-Legal History Review, n ${ }^{\circ}$ 14, 2012; Alfredo Castillero Calvo, "La constitución gaditana de 1812 y su influencia en Panamá: 1808-1821", Memorias: revista digital de historia y arqueología desde El Caribe colombiano, 18, 2012, pp. 55-87; Ana Luz Borrero Vega, "El legado de Cádiz: ciudadanía y cultura política en la Gobernación de Cuenca, 1812-1814", Procesos: revista ecuatoriana de historia, $n^{\circ}$ 39, 2014, pp. 9-36; María de los Ángeles Castro Pirela "La nueva simbología en Venezuela a través de actos de jura, festividades y música a principios del siglo XIX", Telos: Revista de Estudios Interdisciplinarios en Ciencias Sociales, vol. 20, n 1: 2018, pp. 58-81.

3 Gabriel Cid, "Ritos para una nueva legitimidad: ceremoniales constitucionales y republicanismo en Chile (1812-1833)", Historia critica, n 47, 2012, p. 26.

4 David González Cruz, De la Revolución Francesa a la Guerra de la Independencia. Huelva a fines de la Edad Moderna, Consejería de Cultura/Fundación El Monte, Sevilla, 2002, p. 105; Julián Andrei Velasco Pedraza, "Fiesta y poder: Persistencia y significaciones de las representaciones sobre el poder en la ciudad de Panamá a través de las juras, 1747-1812", Boletín de la AFEHC, $\mathrm{n}^{\circ}$ 48, 2011; Julián Andrei Velasco Pedraza, "Celebrar el poder: juras y proclamaciones en el Nuevo Reino de Granada, 1747-1812”, en Orián Jiménez Meneses y Juan David Montoya Guzmán (eds.), Fiestas, memoria y nación. Ritos, símbolos y discursos, 1573-1830, 
nuevo tiempo auspiciado por la Constitución de Cádiz no pudo sustraerse, por tanto, de determinadas actuaciones e inercias procedentes de la etapa anterior, si bien es cierto que el significado de estos elementos tradicionales pudo adoptar nuevas acepciones en su reedición y reutilización por parte del nuevo régimen.

En definitiva, a la hora de dar cuenta de las proyecciones y confluencias de uno y otro tiempo resulta adecuado dirigir la mirada sobre ciertos episodios que, siguiendo las pautas marcadas por los poderes superiores, se desarrollaron bajo procedimientos previamente delimitados, pero sin obviar en este punto otras dimensiones menos sistematizadas y regladas que les acompañaban y que respondian a dinámicas más concretas, apegadas a realidades definidas en clave local, donde se hacian presentes elementos tanto del pasado como del presente y cuya materialización específica quedaba marcada por lecturas generadas al interior de la comunidad. La escala municipal seguía configurándose, por tanto, como una pieza básica del sistema, también a la hora de difundir y adscribirse públicamente a los nuevos instrumentos políticos proyectados desde Cádiz.

Partiendo de estas consideraciones, este trabajo pretende incorporar al análisis la perspectiva espacial, considerando así realidades vecinales distintas, en las que no solo cabría contemplar dinámicas y tradiciones propias cultivadas a lo largo del tiempo, sino también las diferentes circunstancias en las que tuvieron que desenvolverse durante la Guerra de la Independencia.

El suroeste peninsular reúne características muy interesantes al respecto. La entrada de los franceses en Sevilla a principios de febrero de 1810 trajo consigo trascendentales novedades para los pueblos de aquel espacio. Por un lado, por la presencia de fuerzas bonapartistas que, atraídas principalmente por el control de los puertos de los ríos Tinto y Odiel, mantenían su base principal en el Condado, en el que fijaban su acuartelamiento en el pueblo amurallado de Niebla y proyectaban desde ese enclave un dificil control sobre las poblaciones del entorno -con acuartelamientos secundarios en Lucena del Puerto, Palos de la Frontera y Moguer-, que combinaban asimismo, ante la imposibilidad de una ocupación efectiva de un espacio tan amplio y agreste, con el envío de columnas móviles en la larga y dura guerra de desgaste contra los defensores de la causa fernandina ${ }^{5}$. Por otro, porque a la frontera tradicional definida por el Guadiana y que marcaba la separación de los dos reinos peninsulares venía ahora a sumarse una segunda línea fronteriza en torno al río Odiel que resultaba más cambiante y flexible, y que determinaba la división entre las tierras ocupadas por los franceses $\mathrm{y}$ aquellas otras que estaban al margen de su control permanente.

La salida de los franceses del suroeste en el verano de 1812 permitía reunir de nuevo bajo un mismo poder a los distintos pueblos de la región, entre cuyos primeros momentos de identificación pública se encontrarian la publicación y el

Universidad Nacional de Colombia/Vicerrectoría General/Comisión para la Celebración del Bicentenario de la Independencia, Bogotá, 2011, pp. 107-129.

5 María Antonia Peña Guerrero, El tiempo de los franceses. La Guerra de la Independencia el suroeste español, Ayuntamiento de Almonte, Almonte, 2000, pp. 23-24; María Antonia Peña Guerrero, “¿Guerra de conquista o guerra de requisa? La Guerra de la Independencia en la provincia de Huelva", en José Miguel Delgado Barrado (dir.), Andalucía en guerra, 1808-1814, Universidad de Jaén, Jaén, 2010, p. 192; Juan Villegas Martín y Antonio Mira Toscano, El mariscal Copons y la defensa del territorio onubense en 1810-1811. Con la edición facsimil del Diario de las Operaciones de la División del Condado de Niebla... Universidad de Huelva, Huelva, 2011, pp. 23-25. 
juramento de la Constitución de Cádiz. En definitiva, la incorporación de la perspectiva espacial en general, y la mirada desde el suroeste en particular, puede aportar algunas claves de interpretación en torno a los significados que, desde enfoques distintos y complementarios, alcanzaron los primeros actos de adscripción pública al nuevo régimen liberal.

\section{EL MARCO NORMATIVO Y SU PROYECCIÓN PÚBLICA Y SOCIAL}

La Constitución de 1812 requirió desde un principio el concurso del conjunto de la nación, que las propias autoridades gaditanas trataron de conseguir, en la línea del ceremonial revolucionario francés ${ }^{6}$, a través de la fórmula del juramento. De ahí que, como recuerda Marta Lorente, la Constitución se juró "en múltiples ocasiones y por una pluralidad de sujetos" 7 . De hecho, las Cortes comenzaron a preparar el ceremonial cuando su articulado estaba prácticamente concluido $^{8}$ y establecía el procedimiento a seguir: el 18 de marzo de 1812 se firmaba el decreto que mandaba su impresión y publicación, así como el que determinaba las solemnidades a considerar en todos los pueblos, el ejército y la armada, y que resolvía hacer asimismo la visita de cárceles; y el 22 de mayo se decretaba que el clero y el pueblo debían prestar juramento a un mismo tiempo y sin preferencia ${ }^{9}$. No se trataba de una cuestión menor porque, como ha planteado Roberto J. López ${ }^{10}$, el conocimiento y el juramento del texto constitucional era la condición primera para su posterior aplicación, de ahí los apremios en la convocatoria para realizar tanto las solemnidades como las notificaciones ante las autoridades superiores.

En lo que respecta al protocolo de actuación, los poderes locales, junto al resto de autoridades y corporaciones, debían desempeñar un papel clave en la transmisión y el juramento del nuevo código en las diferentes ciudades y villas. E incluso el relato sobre su desarrollo era compuesto, o al menos supervisado, desde las filas de los respectivos cuadros de gobierno municipal ${ }^{11}$, circunstancia

\footnotetext{
6 Jean Starobinski, 1789. Los emblemas de la razón, Taurus, Madrid, 1988; Mona Ozouf, La fête révolutionnaire, 1789-1799, Gallimard, París, 1989; Gonzalo Butrón Prida, "Fiesta y revolución: las celebraciones políticas en el Cádiz liberal (1812-1837)", en Alberto Gil Novales (ed.), La Revolución Liberal, Ediciones del Orto, Madrid, 2001, pp. 159-177; Carlos Reyero, Alegoría, Nación y Libertad: el Olimpo constitucional de 1812, Siglo XXI, Madrid, 2010.

7 Marta Lorente Sariñena, "La Nación y las Españas", en Bartolomé Clavero, José María Portillo y Marta Lorente, Pueblos, Nación, Constitución (en torno a 1812), Ikusager, Vitoria-Gasteiz, 2004, p. 113.

8 Pablo Alberto Mestre Navas, "Publicación y ceremonial de la Constitución de Cádiz, un análisis desde las Ciencias y Técnicas Historiográficas", en Felipe Lorenzana de la Puente y Rogelio Segovia Sopo (coord.), XIII Jornada de Historia de Fuentes de Cantos: Bicentenario de la Constitución de 1812 y otros estudios sobre Extremadura, Asociación Cultural Lucerna, Fuentes de Cantos, 2012, p. 174.

9 Decretos publicados en Constitución política de la Monarquía Española, promulgada en Cádiz el 19 de marzo de 1812, En la Imprenta Real, Cádiz, 1812.

10 Roberto J. López, “Hablar a la imaginación'. Las ceremonias de proclamación y jura de la Constitución de 1812 en el noroeste peninsular", Obradoiro de Historia Moderna, $\mathrm{n}^{\circ}$ 20, 2011, p. 145 .

${ }^{11}$ La documentación disponible y utilizada en este trabajo se corresponde básicamente con las certificaciones que, firmadas en cada caso por los respectivos escribanos de cabildo, se remitieron entonces a las Cortes y se conservan hoy en el Archivo del Congreso de los Diputados.
} 
que viene a condicionar en última instancia nuestro propio acercamiento a la práctica concreta desarrollada en los distintos marcos comunitarios.

Los actos, según establecía la propia normativa, distinguían dos tipos de ceremonias: una correspondiente a su publicación en lugar público y lectura en voz alta -con especial protagonismo del poder civil-, y que debía concluir, allí donde fuese posible, con repiques de campana, iluminación y salvas de artilleria; y otra respecto a su jura en la parroquia el siguiente día festivo al primer acto de publicación, que debía contar, además, con la exhortación de un representante eclesial y que se cerraba cantando el tedeum. Y es que la Iglesia, llamada a proyectar su potestad moral sobre el texto constitucional ${ }^{12}$, tendría un papel central en aquellos actos. El ceremonial requería asimismo, por tanto, de la colaboración del clero parroquial, circunstancia que fue impulsada además por las autoridades eclesiásticas superiores: por ejemplo, como indicaba el comisionado especial en Ayamonte para todos los asuntos eclesiásticos que ocurriesen en los pueblos libres del arzobispado, ninguna excusa por parte del clero debía dilatar "un momento el exacto cumplimiento de tan importantes soberanas determinaciones"13. Así pues, el tejido institucional municipal, tanto civil como eclesiástico, y las prácticas ceremoniales del pasado tendrian un protagonismo muy destacado en la circulación, la recepción y el juramento vecinal del texto constitucional ${ }^{14}$.

Más allá de las disposiciones normativas o de los artificios que pudiesen presentar en algún momento las fuentes conservadas ${ }^{15}$, lo cierto es que desde el punto de vista historiográfico no existe un relato cerrado en torno al sentido último de la fórmula, ni sobre su naturaleza o alcance dentro del nuevo contexto abierto con las Cortes y la Constitución ${ }^{16}$. En todo caso, los actos de publicación y juramento de la Constitución, planteados como el momento fundacional del nuevo compromiso político y como antesala de la aplicación práctica de su contenido, necesitaban de la puesta en marcha de un ritual que no solo hiciese comprensible para el conjunto de la población el significado de las transformaciones, sino que facilitase también su fidelidad pública hacia la nueva norma y el sistema que se sustentaba en ella ${ }^{17}$. En este sentido no se debe obviar

12 Amelia Sanchis Vidal y María José Ramos Rovi, "Influencia del catolicismo en la Constitución gaditana: análisis del juramento y la representación eclesiástica por Andalucia", Hispania Sacra, vol. LXIX, n 139, 2017, pp. 311-313.

13 Escrito dirigido al cura más antiguo de Ayamonte con fecha 25 de julio de 1812 y donde refería trasladar orden del secretario del Cardenal Arzobispo del 2 de ese mismo mes. Archivo Histórico del Arzobispado de Sevilla (en adelante AHAS), Gobierno/Asuntos despachados, leg. 134, año 1812, s.f.

14 François-Xavier Guerra, Modernidad e independencias. Ensayos sobre las revoluciones hispánicas, Mapfre, Madrid, 1992, p. 295.

15 Julián Andrei Velasco Pedraza, "Celebrar el poder: juras y proclamaciones en el Nuevo Reino de Granada, 1747-1812”, op. cit., pp. 110-111.

16 Fernando Martínez Pérez, "La dimensión jurídica del juramento constitucional doceañista", en Alberto Ramos Santana y Alberto Romero Ferrer (eds.), 1808-1812: los emblemas de la libertad, Universidad de Cádiz, Cádiz, 2009, pp. 377-392.

17 María José Garrido Asperó, "Los regocijos de un Estado liberal: la discusión en las Cortes Generales y Extraordinarias de Cádiz sobre las fiestas que celebrarian a la monarquía constitucional", Secuencia, n 50, 2005, p. 204; Manuel Hernández González, "La fiesta patriótica. La jura de la Constitución de Cádiz en los territorios no ocupados (Canarias y América), 1812- 
que, como refiere Roberto J. López, el propio ceremonial tendría por objeto la adhesión de todo el cuerpo social, no bajo el prisma de la racionalidad sino a partir de la movilización de sus sentimientos, de ahí que para popularizar conceptos como nación, patria, libertad, igualdad, soberanía nacional o parlamentarismo, se acompañasen los eventos con el levantamiento de arquitectura efimera alusiva a esos ideales, así como con textos que hacian explícito el contenido de los simbolos ${ }^{18}$. En estas circunstancias, ese marco festivo y ritual terminaba adquiriendo componentes innovadores ${ }^{19}$ y se dotaba de novedosos significados en conexión con su misma filiación liberal y en contraposición con la fiesta barroca absolutista ${ }^{20}$.

Por otro lado, en relación al quién y el cómo se juraba la Constitución, hay que considerar el protagonismo de la fórmula corporativista y no individual21, circunstancia que quedaba acentuada además por su distribución por parroquias, las cuales constituian la cédula básica de la sociabilidad tradicional ${ }^{22}$ y, como tal, cumplían un importante papel tanto en la organización del espacio religioso como en la ordenación del territorio y de la vida comunitaria en su

1814", en Alberto Ramos Santana y Alberto Romero Ferrer (eds.), 1808-1812: los emblemas de la libertad, Universidad de Cádiz, Cádiz, 2009, p. 90; Amelia Sanchis Vidal y María José Ramos Rovi, "Influencia del catolicismo en la Constitución gaditana: análisis del juramento y la representación eclesiástica por Andalucía”, op. cit. p. 313.

18 Roberto J. López, “'Hablar a la imaginación'. Las ceremonias de proclamación y jura de la Constitución de 1812 en el noroeste peninsular”, op. cit., pp. 144 y 149.

19 Fernán Altuve-Febres Lores, "De las juras reales al juramento constitucional: trayectoria de un sacramento político", en José de la Puente Brunke y Jorge Armando Guevara Gil (eds.), Derecho, instituciones y procesos históricos. XIV Congreso del Instituto Internacional de Historia del Derecho Indiano, tomo III, Pontificia Universidad Católica del Perú, Lima, 2008, p. 155.

20 Siguiendo esta misma lógica, las celebraciones cívico-religiosas ocuparian, como ha señalado David López Viera, un lugar central en los primeros momentos de la vuelta al orden anterior. Los festejos de 1814 y 1823, después de sendos periodos de vigencia de la Constitución de 1812, estaban "revestidos de una ritualización y una estética plenamente barrocas", a partir de los cuales "se intentaba conmover los sentimientos del pueblo, acercándolo afectivamente a la forma de gobierno del Estado absoluto, en línea con las tácticas empleadas por el Poder a lo largo de los tres siglos que abarca la Modernidad". David López Viera, "Las celebraciones absolutistas en Huelva en el ocaso del Antiguo Régimen: intentos de restablecimiento del mismo en las mentalidades colectivas", en Francisco Núñez Roldán (coord.), Ocio y vida cotidiana en el mundo hispánico en la Edad Moderna, Universidad de Sevilla, Sevilla, 2007, pp. 477-482.

21 Marta Lorente Sariñena, "El juramento constitucional", Anuario de Historia del Derecho Español, tomo LXV, 1995, pp. 585-632; Marta Lorente Sariñena, "El juramento constitucional: 1812", en Pablo Fernández Albaladejo y Margarita Ortega López (eds.), Antiguo Régimen y Liberalismo: Homenaje a Miguel Artola. 3. Politica y Cultura, Alianza, Madrid, 1995, pp. 209-229; Marta Lorente Sariñena, "La Nación y las Españas", op. cit.; Federica Morelli, "La publicación y el juramento de la Constitución de Cádiz en Hispanoamérica. Imágenes y valores (1812-1813)", en Johannes-Michael Scholz y Tamar Herzog (eds.), Observation and Communication: The Construction of Realities in the Hispanic World, Klostermann, Frankfurt, 1997, pp. 133-156; Salvador Cárdenas Gutiérrez, "De las juras reales al juramento constitucional: tradición e innovación en el ceremonial novohispano, 1812-1820", en La supervivencia del derecho español en Hispanoamérica durante la época independiente, UNAM, México, 1998, pp. 63-94.

22 François-Xavier Guerra, "E1 soberano y su reino. Reflexiones sobre la génesis del ciudadano en América Latina", en Hilda Sábato (coord.), Ciudadanía politica y formación de las naciones. Perspectivas históricas de América Latina, Fondo de Cultura Económica, México, 1999, pp. 33-61. 
conjunto, particularmente en el mundo rural ${ }^{23}$. En definitiva, si a la celebración en las parroquias se le suma la tradicional confesionalidad de sus habitantes, no sorprende que fuesen actos masivos y que contasen con la presencia no solo de aquellos vecinos que, gracias al texto constitucional que entonces juraban, obtenian el derecho al voto ${ }^{24}$.

Esta última cuestión nos sitúa frente al escenario del significado y la intencionalidad de los que fueron dotados aquellos actos, y no exclusivamente por parte de las autoridades de Cádiz. En este sentido, pese a que no han faltado algunas aportaciones respecto a las lecturas que sobre él hacian los receptores del juramento ${ }^{25}$, desde este enfoque de trabajo quedan sin embargo diferentes aspectos por resolver de manera satisfactoria, particularmente porque no han sido incorporados al estudio, o al menos en toda su extensión, algunas variables que pueden ayudar a la comprensión del fenómeno en su conjunto. Por una parte, habría que cuestionarse si aquellos actos, dotados de unos rasgos ceremoniales uniformes establecidos normativamente, fueron vividos $\mathrm{y}$ representados de distinta manera en función de las características del cuerpo social o de otros aspectos de carácter espacial o cronológico. Por otra, acerca del papel que tendría la historia más inmediata, así como los esfuerzos y las expectativas que se fueron generando en los distintos pueblos durante los difíciles años de la guerra.

En buena medida, el análisis del suroeste ofrece la posibilidad de atender a algunos de los fenómenos reseñados, particularmente desde tres ejes clave que se presentan de manera interrelacionada: la cronologia, la geografia y el ritual festivo. Y con ello, contribuir al debate en torno a la naturaleza y la dimensión precisa de los actos de publicación y juramento constitucional, una cuestión que no puede desligarse de otra mayor referida a los procesos de politización y densificación del espacio público en los inicios de la contemporaneidad.

\section{RITUALIDAD FESTIVA, TIEMPO Y ESPACIO. LECTURAS DESDE LOS MÁRGENES}

Las distintas comarcas del suroeste no tuvieron un mismo modelo de ocupación ni padecieron la presencia francesa durante el mismo tiempo y con la misma intensidad. Así, por ejemplo, los pueblos al sur situados entre los ríos Odiel y Guadiana estarian al margen del control directo de los franceses, que incursionarian en aquel espacio de manera puntual, de ahí que quedasen adscritos -aunque no sin dificultades ni obstáculos- al marco político e institucional proyectado por las autoridades de Cádiz. Los pueblos de la Sierra de Aracena y Picos de Aroche, más al norte, asistirian a los movimientos y enfrentamientos de uno y otro ejército desde la llegada de los franceses a la región, los cuales no pudieron establecerse de manera más estable y continuada

23 Roberto J. López, “'Hablar a la imaginación’. Las ceremonias de proclamación y jura de la Constitución de 1812 en el noroeste peninsular", op. cit., pp. 163-164.

24 Amelia Sanchis Vidal y María José Ramos Rovi, "Influencia del catolicismo en la Constitución gaditana: análisis del juramento y la representación eclesiástica por Andalucía", op. cit. pp. 312-313.

25 Federica Morelli, "La publicación y el juramento de la Constitución de Cádiz en Hispanoamérica. Imágenes y valores (1812-1813)”, op. cit., p. 149. 
hasta finales de 1811, momento a partir del cual lograban aplicar, si bien en paralelo con la reactivación de la actividad bélica, algunos cambios y medidas de gobierno, lo que en el caso de algunos de aquellos pueblos se tradujo en la conformación de nuevos ayuntamientos siguiendo las disposiciones bonapartistas $^{26}$. Y en la comarca del Condado de Niebla y de su entorno más inmediato, de localización más próxima a Sevilla, se establecía el cuartel general de las tropas francesas ${ }^{27}$, quedando ocupada en lineas generales entre los primeros meses de 1810 y agosto de 1812, y, en consecuencia, participando a lo largo de aquel tiempo -aunque con diferencias según los distintos casos particulares- de la legalidad proyectada por la nueva dinastía.

El análisis de la publicación y el juramento celebrados en algunos de los pueblos situados en las comarcas descritas permite conjugar diferentes variables que incluyen no solo las realidades concretas ajustadas al espacio geográfico en las que se insertaban, sino también los momentos y los contextos precisos en los que se desarrollaron y las expresiones y rituales simbólicos específicos con los que se llevaron a la práctica. Tres ejes que, de manera combinada, pueden contribuir a trazar nuevas vías de acercamiento en torno a sus significados y proyecciones al interior de la comunidad local dentro del escenario de politización y densificación del espacio público traído por los nuevos tiempos.

\subsection{Entre el Guadiana y el Odiel}

La ciudad de Ayamonte, enclave fronterizo situado en la desembocadura del Guadiana, no solo se había mantenido al margen del control francés permanente sino que además había representado un papel clave tanto en la defensa de los intereses fernandinos en la región como en la dinamización de las vías de comunicación abiertas en el arco atlántico, desde el Algarve a Cádiz. Precisamente, respondiendo a ese protagonismo, a la amplitud del cuerpo político e institucional que se localizaba en su marco municipal y a las lógicas corporativas que articulaban todo el proceso, sería el primer pueblo en asistir a los actos de publicación y juramento constitucional, los cuales tomaban cuerpo, en distintos momentos y sobre diferentes colectivos, desde los primeros dias del mes de julio de $1812^{28}$.

El 5 de julio se realizaron la lectura y la jura entre los empleados del correo de la ciudad, quienes tendrian el encargo de llevar la Constitución a los pueblos del entorno. En el juramento, efectuado por todos los asistentes -de manera individual pero bajo la lógica corporativa- una vez que habian mostrado su entendimiento y entusiasmo, se recurría a símbolos y recursos propios del ritual católico por cuanto lo harian con las manos puestas sobre un libro de los Santos Evangelios situado en el altar y ante una imagen de Jesucristo29. En la

$26 \mathrm{M}^{\mathrm{a}}$ Teresa Menguiano Romero, La Guerra de la Independencia en la Sierra de Huelva, Diputación Provincial de Huelva, Huelva, 2017, pp. 67-73.

27 María Antonia Peña Guerrero, El tiempo de los franceses. La Guerra de la Independencia el suroeste español, op. cit., p. 24.

28 José Saldaña Fernández, "Ayamonte y su entorno en 1812: la publicación y el juramento constitucional", en XVII Jornadas de Historia de Ayamonte, Diputación Provincial de Huelva/Ayuntamiento de Ayamonte, Huelva, 2013, pp. 181-200.

29 Archivo del Congreso de los Diputados (en adelante ACD), Serie General de Expedientes (en adelante SGE), leg. 25, $\mathrm{n}^{\circ} 1$, doc. 20. 
certificación se recogían algunas de las claves que definirian otros procesos que se dieron a continuación: tanto por la participación destacada de algún miembro de la corporación municipal y la importancia de la ritualidad religiosa y la fórmula colectiva que adoptaba la adscripción pública, como por la construcción del relato que se componía sobre ello, en el cual se destacaban los signos de júbilo y entusiasmo que mostraban sus participantes.

Así debió de ocurrir en los actos efectuados por las tropas militares que el 19 de julio se encontraban en la ciudad. Y, por supuesto, en los realizados entre el $25 \mathrm{y}$ el 27 por la comunidad local en su conjunto ${ }^{30}$, un momento álgido en el proceso de adscripción a la Constitución, tanto por la resonancia pública que alcanzaba, como por la amplitud y variedad de agentes implicados en el mismo: desde las autoridades municipales en sus distintas variantes jurisdiccionales -cuerpos militares, poderes civiles o religiosos-, hasta la población asentada en ese momento en la ciudad avecindada o residente circunstancial-, que, en lineas generales, tenía intereses diferentes y que, al menos sobre el papel, acudiria de forma libre y voluntaria a la convocatoria para participar de manera honrosa y celebrativa en aquellos actos.

No hay que obviar, con todo, que la certificación que debía remitirse a las autoridades superiores condicionaria tanto la realidad de aquellos actos como la representación que se hacía de esa misma realidad. Es decir, lo que se evidenciaba en esos testimonios era, por un lado, que los poderes locales se habian esforzado para que los actos se resolviesen conforme a la normativa y de la manera más honorable posible, y, por otro, que el pueblo había participado en gran número $\mathrm{y}$ de forma entusiasta, mostrando en todo momento su entendimiento y adscripción ferviente al texto constitucional.

Otra cosa distinta sería determinar la eficacia real de aquellos actos. Como cabe suponer, en la fase de preparación de estos eventos, las autoridades locales generarian el caldo de cultivo para que la respuesta popular resultase de lo más apropiada a sus propios intereses institucionales. En cierta manera, ello haria aminorar los efectos que pudiese haber tenido la falta de atención y el escaso entendimiento que, según se ha destacado en otros trabajos ${ }^{31}$, debió de caracterizar no solo la lectura en alta voz de la Constitución, sino incluso los sermones que la acompañaron, particularmente en aquellos momentos que se abordasen cuestiones de fondo y se sobrepasase, por tanto, el simple marco retórico y las referencias estrictamente patrióticas.

Todo ello no podría considerarse sin atender además a dos ejes de relación básicas: el cuadro de los asistentes y la naturaleza de los discursos. La composición poblacional de Ayamonte en julio de 1812 debió de resultar muy variada y compleja, no solo por la presencia de numerosos refugiados llegados de puntos más o menos distantes, sino también por la salida de muchos de sus vecinos con dirección a lugares menos gravosos y exigentes, particularmente de aquellos que disponían de una mayor capacitación económica y social para la participación y el entendimiento de las cuestiones públicas ${ }^{32}$. Hay que tener en

30 No quedaba cerrado en esos días el proceso, ya que el 31 de julio lo harian los oficiales de la milicia urbana de la ciudad. ACD, SGE, leg. $25, \mathrm{n}^{\circ} 1$, doc. 20, s.f.

31 Roberto J. López, “'Hablar a la imaginación'. Las ceremonias de proclamación y jura de la Constitución de 1812 en el noroeste peninsular", op. cit., pp. 157-158.

32 Circunstancia recogida explícitamente en documentos como el firmado en Ayamonte a 3 de diciembre de 1811. Archivo Municipal de Ayamonte, Actas Capitulares, leg. 23, s.f. 
cuenta además que por aquellas fechas volvía a constatarse la presencia por la zona de tropas bonapartistas y que, en consecuencia, algunos pueblos del entorno se vieron obligados a retrasar la celebración de los actos que ya tenían programados. Tales fueron los casos de Puebla de Guzmán ${ }^{33}$ y El Almendro ${ }^{34}$, en cuyos informes se hacia referencia de forma expresa al aplazamiento de las ceremonias debido a los peligros y las alteraciones que acarreaba la llegada de tropas enemigas. En Cartaya también se verian afectados los actos debido a la emigración del vecindario "y dislocación de los negocios públicos" por la continua entrada de franceses, a lo que habria que sumar además que era época de cosecha y que sus habitantes estaban ocupados en esas labores ${ }^{35}$. En este contexto, las autoridades de Villablanca promovieron algunos dias antes de la publicación prevista para el 15 de agosto la difusión de información sobre la convocatoria para que llegase a conocimiento de todos los vecinos, incluida aquella parte que había emigrado "por las circunstancias que no se ignoran", para que así pudiesen participar en el ceremonial ${ }^{36}$.

A los peligros por la proximidad de los franceses y sus efectos sobre la celebración de la publicación y el juramento constitucional habría que sumar las derivaciones acerca del nivel de comprensión de los asistentes sobre el texto al que entonces se adscribian públicamente, el cual debió de resultar no solo limitado sino desigual. Limitado porque buena parte de su articulado resultaría de difícil entendimiento para la totalidad de los concurrentes más allá de las consignas generales y simplificadas que pudieron articularse a partir del mismo. Y desigual porque no todos los participantes dotarian de un mismo significado a aquellos acontecimientos. Para unos representarían, en conexión con los discursos y las prácticas patrióticas de los que no solo eran receptores sino también partícipes de su construcción y difusión desde el inicio de la guerra, una nueva evidencia de los avances que, en el terreno de la confrontación bélica, tendría la causa fernandina. Para otros, en cambio, vendrian a representar asimismo el episodio inaugural de un nuevo tiempo político, también a nivel municipal, como quedaba constatado por la rápida gestión del ayuntamiento de Ayamonte, quien varios días después del juramento constitucional acordaba, siguiendo lo recogido en la Constitución y en algunos decretos de las Cortes, el cese de los alcaldes mayores y corregidores en el ejercicio de la jurisdicción politica, reasumiendo desde ese momento la corporación el mando político de la ciudad y resolviendo con ello algunos problemas de carácter jurisdiccional abiertos desde algún tiempo atrás ${ }^{37}$.

Ahora bien, esas lecturas plurales podrian encontrar un punto de intersección en las acciones festivas que debian complementar los actos de publicación y juramento. Las mismas disposiciones superiores recogian que, en caso de ser posible, se realizasen repiques de campana, iluminación y salvas de

33 Actos celebrados finalmente a partir del 2 de agosto. ACD, SGE, leg. 25, no 1 , doc. 122 , s.f.

34 Los actos tuvieron lugar al final el 9 y el 15 de agosto. ACD, SGE, leg. 25, n 1 , doc. 13, s.f.

35 Sesión del ayuntamiento del 25 de agosto de 1812. Archivo Municipal de Cartaya (en adelante AMC), Actas Capitulares, leg. 9, s.f.

36 ACD, SGE, leg. 25, $\mathrm{n}^{\circ} 1$, doc. 161 , s.f.

37 Ayamonte, 28 de julio de 1812. AHAS, Gobierno/Asuntos despachados, leg. 136, año 1812, s.f. 
artillería para celebrar y recalcar la importancia de aquel acontecimiento, lo que indudablemente no haría sino inculcar un cierto entusiasmo celebrativo en todos los habitantes de la ciudad -hombres, mujeres, adultos, niños, avecindados, residentes ocasionales...-, y, en consecuencia, una más eficiente consideración pública sobre su significación y trascendencia como signo clave de un nuevo tiempo. No hay que perder de vista, según sostiene Carlos Reyero, que la celebración pública, en combinación con los textos e imágenes creados para su difusión, contribuyeron a la presentación de las transformaciones institucionales como un hecho festivo para el disfrute al que no había que tener miedo; de la misma forma que, además de ese punto de frivolidad, la fiesta se asociaba al culto a los simbolos propios de un ritual religioso ${ }^{38}$.

Sorprende, sin embargo, que este apartado festivo complementario no alcance proyección en un pueblo como Ayamonte, al menos si seguimos la descripción recogida en la certificación. Y sorprende aún más si tenemos en cuenta el alcance que este campo tuvo en otros municipios del entorno, tanto en los juramentos realizados en fechas próximas al del enclave fronterizo, como en aquellos que lo hicieron algún tiempo después.

Entre aquellos pueblos situados próximos a la línea fronteriza del Guadiana y que más rápidamente acometieron la publicación y el juramento podemos destacar el caso de Lepe, cuyos actos dirigidos a toda la población se celebraron, como ocurrió en la desembocadura del Guadiana, entre los días 25 y 26 de julio. No obstante, más allá de esa coincidencia temporal, el ritual festivo resultaba en este caso mucho más rico y atractivo, entre otras cuestiones porque las acciones recogidas en la normativa eran arropadas, por un lado, con la utilización de determinados recursos estéticos y visuales de clara significación e influjo para todos los miembros de la comunidad local, y, por otro, con la proyección de ciertos espacios de celebración reservados exclusivamente a la oligarquía local. En el primer caso, el retrato de Fernando VII ocupó una posición central durante el acto de la publicación, siendo conducido junto a un ejemplar de la Constitución en la procesión que se iniciaba a continuación y que recorria algunas calles del pueblo. En el segundo, se evidenciaba el papel protagonista que ejercieron las élites político-sociales de la localidad en la dirección de los actos, marcando con nitidez no solo los distintos escenarios -físicos o simbólicosen los que debían moverse unos y otros, sino también las diversas acciones festivas en las que debian participar los diferentes miembros de la comunidad: por ejemplo, al final de la lectura en voz pública y después de concluir la procesión se montó un "desente refresco" en el que participaron exclusivamente los sujetos de los dos cabildos junto a las personas de mayor significación del pueblo 39 .

En Puebla de Guzmán los actos iniciados el 2 de agosto, cuando todavía los franceses se localizaban próximos al municipio, además de lo marcado por la normativa, contaron con iniciativas que venian a realzar su ejecución -por ejemplo, la colocación en la plaza para la publicación de mesa, sillas y bancos-, así como de otras acciones festivas que, si bien no se describían en detalle, quedaban definidas en la certificación bajo la fórmula imprecisa de las

38 Carlos Reyero, Alegoría, Nación y Libertad: el Olimpo constitucional de 1812, op. cit., p. 175.

39 ACD, SGE, leg. 25, n⿳0 1, doc. 90, s.f. 
diversiones, todo lo cual venía a demostrar, según destacaba el propio relato, "el repetido regocijo con que se hallaban revestidos los corazones de estos ciudadanos" $"$.

Otros ejemplos posteriores alcanzaron mayores cotas de desarrollo y complejidad en lo concerniente tanto al ritual simbólico como al escenario festivo y celebrativo. Los actos desarrollados en la villa de El Almendro durante los dias 9 y 15 de agosto resultaron especialmente significativos. Por una parte, porque la publicación se envolvía de signos litúrgicos muy llamativos visualmente y dotados de cierta teatralidad -posición de rodillas de los asistentes y colocación de la Constitución sobre la cabeza del alcalde mientras que era besada por todos los componentes del cabildo, mostrando el resto de concurrentes el deseo de practicar esa misma diligencia-, cuyos referentes más inmediatos los encontramos en la propia ritualidad católica. Por otra, porque tanto ese acto como el juramento contaron con la participación y la complicidad, ya fuese de manera espontánea -entre las muestras de júbilo de aquellos dias se dieron "repetidos vivas, hasta el sexo femenino y muchachos"- o inducida -se llegó a estipular, bajo amenaza de multa, la asistencia obligatoria para todos los moradores, incluidos los "niños hasta la edad de siete años"-, de buena parte de los entonces residentes en la localidad, incluso de aquellos que disponían de una menor capacitación pública y social ${ }^{41}$.

La publicación y el juramento en El Almendro estuvieron dotados de contenidos y significados que incorporaban espacios simbólicos y de adscripción comunitarios a partir de los cuales se pueden extraer algunas consideraciones más generales. Por un lado, porque el ritual que precedió a la lectura en voz pública implicaba una cierta sacralización del texto constitucional, lo que entrañaba a su vez el manejo de ciertos códigos mentales y sentimentales acordes con el marco sensitivo y afectivo tradicional y con prácticas religiosas muy asentadas y reconocidas por todos. Por otro, porque la participación de mujeres y niños, motivada incluso por el cabildo bajo fórmulas sancionadoras, dotaba a los actos de un sentido de pertenencia y adhesión comunitaria que sobrepasaba con creces el marco restrictivo de los derechos politicos que la misma Constitución amparaba. En buena medida, la potestad moral que otorgaba la Iglesia al juramento se vería reforzada por la presencia en aquella ceremonia de la mayoria del pueblo, incluidos las mujeres y los transeúntes, los cuales no podian sin embargo votar ${ }^{42}$.

Las autoridades de Villablanca pusieron también un especial interés en garantizar la participación y la complicidad de todos los habitantes durante los actos del 15 y 16 de agosto a través de una doble via. Por una parte, promoviendo una convocatoria general que pretendía conseguir incluso la concurrencia de los vecinos que se encontraban emigrados. Por otra, impulsando un marco conmemorativo de fondo en el que se mezclaban elementos sensitivos -visuales y sonoros- de claras referencias festivas y religiosas y que ejercería de mecanismo integrador dentro de la comunidad, con independencia del género, edad y

40 ACD, SGE, leg. 25, $\mathrm{n}^{\circ} 1$, doc. 122 , s.f.

41 ACD, SGE, leg. 25, $\mathrm{n}^{\circ} 1$, doc. 13, s.f.

42 Amelia Sanchis Vidal y María José Ramos Rovi, "Influencia del catolicismo en la Constitución gaditana: análisis del juramento y la representación eclesiástica por Andalucía", op. cit. p. 313. 
procedencia: no en vano, llegó a darse un refresco general al que asistió buena parte de los residentes y se montó un baile en la plaza que tuvo una duración de cinco horas, "cosa que va corriendo para tres años no se ha visto en este pueblo"43.

Esa última referencia dejaba a las claras, pues, que los actos retomaban, de forma más o menos acentuada, una práctica festiva de enorme proyección durante el Antiguo Régimen, la cual se había visto drásticamente cortada a causa de la guerra ${ }^{44}$. Repiques de campana, luminarias de casas y calles, e incluso la celebración de bailes, estuvieron presentes durante el siglo XVIII cuando se pretendia celebrar ciertos acontecimientos relacionados con la familia real como bodas, nacimientos o la proclamación del monarca, y volvían a estarlo ahora, durante los procesos de publicación y juramento de la Constitución, por cuanto representaban una ocasión idónea para llevar a cabo una exhibición colectiva y pública cargada de sentimiento.

En fin, aunque en buena parte de los pueblos del entorno el ritual festivo se ceñiría a lo marcado por la normativa, con repiques de campana, salvas o iluminaciones, ello no sería óbice para que las respectivas certificaciones, en caso de que lo permitiesen las circunstancias concretas del lugar ${ }^{45}$, proyectasen un cierto grado de satisfacción por el ambiente festivo en el que se habian desarrollado aquellas jornadas, subrayando asimismo la alegría y el júbilo manifestados entonces por el vecindario ${ }^{46}$. No en vano, como sostenía el ayuntamiento de Cartaya poco antes de la publicación y el juramento, después de que las continuas entradas del enemigo habian provocado la "dislocación de los negocios públicos y desorganización de su vecindario", y encontrándose ya "libres" de "tan deplorable" situación, se hacía necesario "dar a conocer a estos fieles y leales habitantes el codigo fundamental de nuestra Monarquía y fundamento de su futura felicidad", en cuyas circunstancias debian darse, además de repiques de campana y salvas de artillería, "todas las demás demostraciones de placer que deben acompañar un día tan memorable y digno de que se grave en el corazón de todos los buenos Españoles" 47.

43 ACD, SGE, leg. 25, no 1 , doc. 161, s.f.

44 Como ha señalado Manuel José de Lara, la sociedad del Antiguo Régimen fue pública y festiva, contaba con importantes canales de sociabilidad y con una acentuada disposición a la manifestación y exhibición pública y colectiva. Manuel José de Lara Ródenas, Religiosidad y cultura en la Huelva Moderna, Diputación Provincial de Huelva, Huelva, 1995, p. 388.

45 En San Silvestre de Guzmán los actos se celebraron el 19 de julio con algunas muestras de regocijo "según las circunstancias del Pueblo", mientras que en Sanlúcar de Guadiana se llevarian a cabo el 25 y 26 de julio con "las solemnidades, pompas y festividades" que habia permitido la "entidad" del pueblo. ACD, SGE, leg. 25, n 1 , docs. 151 y 144, s.f.

46 Así quedaba de manifiesto en los escritos correspondientes a Villanueva de los Castillejos cuyos actos se celebraron el 16 y 23 de agosto-, Cartaya -29 y 30 de agosto-, Isla Cristina - 6 y 8 de septiembre-, La Redondela -12 y 13 de septiembre-, San Bartolomé de la Torre -24 y 25 de octubre- y El Granado -31 de octubre y 1 de noviembre-. ACD, SGE, leg. 25, no 1, docs. 169, 37, $83,134,140$ y 78 .

4725 de agosto de 1812. AMC, Actas Capitulares, leg. 9, s.f. 


\subsection{La Sierra de Aracena y Picos de Aroche}

En los pueblos de la Sierra de Aracena y Picos de Aroche la situación resultaría algo diferente. Configurada como una zona de enfrentamientos y escaramuzas, no seria hasta finales de 1811 cuando la presencia francesa resultase algo más constante y estable. En tal circunstancia habría que esperar también a la retirada definitiva de los franceses del suroeste en el verano de 1812 para la realización de los actos públicos de adhesión al texto constitucional gaditano, algunos de los cuales se acompañaron además de los primeros ajustes respecto al nuevo marco político e institucional ${ }^{48}$.

Entre los ejemplos analizados, los primeros pueblos en poner en marcha los actos de adscripción pública a la Constitución serían Aroche, Encinasola y Castaño del Robledo. En los tres casos la publicación tendría lugar el 25 de julio - "día del patrón de las Españas", como recogía la certificación del primer pueblo49-, y el juramento el 26 - "día de nuestra Señora Santa Ana", como lo hacía la del último ${ }^{50}$. Algo más completo en Aroche -el 27 se hizo la visita de la cárcel-, los tres enclaves terminaban desarrollando una ritualidad muy parecida y en buena medida restringida a lo marcado por la normativa: lectura en la plaza pública acompañada de repiques de campana, salvas de tiros e iluminación general por la noche ${ }^{51}$; y juramento en la iglesia, con referencia en algún caso a que se había hecho con la solemnidad requerida, pero sin especificar nada más respecto a otros episodios festivos en aquel dia ${ }^{52}$.

Las certificaciones correspondientes a actos del mes de agosto -aunque en algunos casos compuestas a lo largo de octubre-, recogian en cambio referencias más extensas y detalladas respecto a lo vivido tras el juramento: eso sí, principalmente mediante fórmulas generales que, además de aludir a repiques, salvas o iluminaciones, resaltaban la felicidad y el alborozo del vecindario. En Jabugo, cuyos actos se efectuaron el 1 y el 2 de agosto, las celebraciones del primer día se desarrollaron "con júbilo y regocijo" de sus vecinos y las del segundo con el "júbilo de todo el pueblo"53. En Cortegana la publicación tendría lugar el 9 de agosto y se haría con diferentes "festejos", mientras que el juramento efectuado en el siguiente festivo contaria asimismo con los "regocijos

48 Así se ha podido constatar para los casos de La Nava y Santa Ana la Real, en cuyas certificaciones se hacía mención a que pocos días después de llevar a cabo el juramento de la Constitución -en el primer caso el 16 de septiembre, el segundo con fecha de 20 de ese mismo mes- se iniciaba el proceso para la elección del nuevo ayuntamiento constitucional. ACD, SGE, leg. $25, \mathrm{n}^{\circ} 1$, docs. 108 y 147 , s.f.

49 ACD, SGE, leg. $25, n^{\circ} 1$, doc. 19 , s.f.

50 ACD, SGE, leg. 25, $n^{\circ} 1$, doc. 40, s.f.

51 La certificación de Encinasola aludía expresamente a que también se hicieron "otras demostraciones de alegria y regocijo”. ACD, SGE, leg. 25, n 1 , doc. 66, s.f.

52 En el caso de Castaño del Robledo se conservan dos testimonios: uno compuesto por el fiel de fechos del ayuntamiento del 27 de julio, otro del escribano público y secretario del ayuntamiento constitucional del 21 de octubre de 1812. Solo el segundo documento, escrito algún tiempo después del desarrollo de los actos, hacía referencia a las celebraciones que se llevaron a cabo con el juramento: repiques de campana, salvas y "otros festejos públicos" tras la publicación, y otros "regocijos" después del juramento. ACD, SGE, leg. 25, n 1, docs. 39 y 40, s.f.

53 Certificación de fecha 22 de octubre de 1812. ACD, SGE, leg. 25, nº 1 , doc. 87, s.f. 
del pueblo"54. Y en Galaroza la publicación se llevó a cabo el 28 de agosto con "regocijo de campanas y demás actos correspondientes"55, y el juramento el día 30, donde volvía a evidenciarse "mucho júbilo de alegría"56.

Los actos celebrados en otros pueblos de la zona durante los siguientes meses no difirieron en exceso de los casos analizados. En algunos con acciones festivas asociadas a ambos momentos: en Alájar la publicación del 10 de septiembre se efectuó ante un crecido número de vecinos "de todos sexos y edades" que expresaron su satisfacción con salvas y vivas, mientras que a la finalización del juramento el día 13 se asistió de nuevo a "regocijos del pueblo"57; y en Fuenteridos donde la publicación el 11 de septiembre se acompañó entre otras acciones de un "aplauso de todo el congreso" de vecinos, y el juramento, en el mismo dia, de repiques de campana y tiros de escopeta ${ }^{58}$. En otros sin embargo las certificaciones solo recogian celebraciones de júbilo asociadas a la publicación, careciendo el juramento de demostraciones festivas adicionales más allá de lo realizado en la iglesia: en Aracena la lectura del 1 de septiembre ${ }^{59}$ se hizo "con todo el decoro debido a semejante acto", repique de campanas e iluminación 60 ; en Cortelazor se celebró el 17 de octubre "con el aparato y mayor decoro posible" y se acompañó de los acostumbrados repiques e iluminarias ${ }^{61}$; y en Corteconcepción la publicación se desarrolló el 7 de noviembre junto a las muestras públicas usuales ${ }^{62}$.

En conjunto, los ejemplos referidos no presentan un ceremonial muy desarrollado, a lo sumo escasos añadidos respecto a lo marcado por la normativa, en muchas de las ocasiones resueltos además narrativamente bajo fórmulas poco concretas que venian a subrayar el ambiente de regocijo o alegría en el que se desarrollaron aquellos actos. Diferentes serian las experiencias de Almonaster la Real e Higuera de la Sierra, pueblos en los que se pusieron en marcha una

54 Certificación del escribano del número y juzgado de rentas de la villa de fecha 27 de octubre de 1812. ACD, SGE, leg. 25, $\mathrm{n}^{\circ} 1$, doc. 55, s.f.

55 Según la certificación del secretario del ayuntamiento de fecha 29 de octubre de 1812. ACD, SGE, leg. $25, \mathrm{n}^{\circ} 1$, doc. 73 , s.f.

56 Según la certificación del escribano de fechos del 2 de septiembre de 1812. ACD, SGE, leg. $25, \mathrm{n}^{\mathrm{o}} 1$, doc. 73 , s.f.

57 El expediente cuenta con dos certificaciones, una de fecha 27 de septiembre y otra de 16 de octubre. ACD, SGE, leg. 25, $\mathrm{n}^{\circ} 1$, doc. 9, s.f.

58 ACD, SGE, leg. 25, $\mathrm{n}^{\circ} 1$, doc. 72 , s.f.

59 Las certificaciones tendrían fecha de 7 de septiembre y 14 de noviembre. El juramento por parte del vecindario se realizaba el 6 de septiembre, si bien el 7 de agosto ya lo habian hecho el administrador y los dependientes del correo. ACD, SGE, leg. 25, nº 1, doc. 16, s.f.

60 En este acto participaron representantes de siete aldeas, excepto de Puerto Moral, que había realizado la publicación y el juramento por su cuenta a finales de agosto. Precisamente, en la certificación de primeros de septiembre sobre los actos en este último enclave se mezclaba la alegría ante "la agradable noticia" de haber expulsado "con tanto honor nuestras tropas a los vándalos y enemigos de nuestra capital", con el anhelo por la ejecución de las leyes de la "nueva constitución", de ahí que se diese inicio rápidamente a la lectura y el juramento. Esta acción se interpretaba además como un "pequeño obsequio" del "patriotismo y fidelidad de este pueblo". ACD, SGE, leg. 25, $\mathrm{n}^{\circ} 1$, doc. 130, s.f.

61 El juramento se efectuó el siguiente domingo. ACD, SGE, leg. 25, $\mathrm{n}^{\circ} 1$, doc. 56, s.f.

62 Juramento realizado el 29 de septiembre. ACD, SGE, leg. 25, n 1 , doc. 54, s.f. 
práctica festiva más compleja que, sobrepasando lo establecido normativamente, mezclaba elementos civiles y religiosos a partir de referentes simbólicos e identitarios de más largo alcance y recorrido.

Para la publicación de la Constitución en Almonaster la Real, efectuada el 13 de septiembre, se adornaron los balcones de las casas capitulares con "ropas de Damasco" y se colocó un retrato de Fernando VII en el medio "con la debida decencia". Los asistentes, que concurrieron en gran número, mostraron el "mayor júbilo" profiriendo vivas, aclamaciones y salva de tiros, mientras que por la noche hubo "baile público" e iluminación general en todas las calles, y al siguiente día "juego de novillos y toro". En la plaza, lugar central de las celebraciones, estuvo expuesto el retrato del rey, que ocupaba una posición central en el balcón de la casa capitular, y que estaba bajo un dosel con luces encendidas y con dos hombres de guardia, uno a cada lado, vestidos "decentemente y con sable en mano". El juramento fue realizado el dia 20 por todas las personas que habian concurrido "de ambos sexos", y se acompañó de las usuales demostraciones "en celebridad de este acto tan plausible a todo este vecindario"63.

En Higuera de la Sierra, tras el acuerdo efectuado por los cabildos secular y eclesiástico el 8 de septiembre para impulsar la publicación y el juramento, se pondrían en marcha las primeras acciones festivas, entre las que se asistiria incluso a la celebración de un refresco en la plaza. La publicación se desarrolló el día 13 acompañada de algunas iniciativas públicas en expresión del "regocijo que manifiesta este leal Pueblo a la libertad que, con los auxilios del cielo, le han proporcionado los grandes gefes que gobiernan la nación", y a cuya finalización, además de fuegos artificiales o "instrumentos del país", se siguió con "el refresco más concurrido" y una función de toros muy lucida y "bailes públicos" que duraron buena parte de la noche. A la mañana del siguiente día se trajo en procesión al Santísimo Cristo del Rosario, protector del pueblo, desde su ermita hasta la iglesia parroquial, lugar en el que se realizó a continuación el juramento "con el mayor júbilo", concluyéndose aquel acto con una procesión que terminó con el regreso del Cristo a la ermita. En la tarde y noche continuaron los bailes, iluminaciones, refrescos, repiques de campana, salvas, fuegos, "toques de instrumentos del país, y demás como en el día antes", además de un solemne rosario "a María Santísima como Patrona del Reyno"64.

\subsection{El Condado de Niebla}

La comarca del Condado de Niebla y su entorno más inmediato soportaron una ocupación más consistente y continuada, participando así, entre los primeros meses de 1810 y agosto de 1812, de la legalidad bonapartista, si bien con diferencias según las distintas realidades locales. Atendiendo a estas circunstancias, la salida de los franceses de la región impulsaría la realización de la publicación y el juramento constitucional, los cuales se vieron precedidos asimismo por la puesta en marcha de medidas excepcionales como el nombramiento de comisionados para que desempeñasen la labor de difusión y

${ }^{63} \mathrm{ACD}, \mathrm{SGE}$, leg. $25, \mathrm{n}^{\circ} 1$, doc. 14 , s.f.

${ }^{64}$ ACD, SGE, leg. $25, \mathrm{n}^{\circ} 1$, doc. 81 , s.f. 
aplicación de las instrucciones salidas desde Cádiz ${ }^{65}$. Las dificiles condiciones de vida de aquellos años, por un lado, y la nueva configuración del poder que traía consigo la victoria de la causa fernandina, por otro, propiciarian que en muchos de estos enclaves, además de asistirse a iluminaciones, repiques, salvas y vivas de la población ${ }^{66}$, se proyectase un ritual festivo de más o menos complejidad que terminaba dotándoles no solo de singularidad y atractivo, sino también de significación y proyección pública en consonancia con el nuevo escenario de adscripciones politicas que se abría en aquel tiempo.

En Trigueros desde la noche antes a la publicación comenzaron "las mayores demostraciones de alegria" ante la expectativa de "experimentar y ver el Acto más grande de la Nación". Al siguiente día 2 de septiembre se llevaba a cabo el primero de los actos en la plaza pública, que fue adornada con "la mayor decencia" y colocado en su centro un retrato de Fernando VII bajo dosel y cubierto con velo, delante del cual se situó un ejemplar de la Constitución en una mesa. Encontrándose la plaza llena con el vecindario, mujeres y niños incluidos, comenzaba el acto descubriéndose el retrato del rey "a golpe de un repique general, orquesta de música y salva de fusilería, con vivas y aclamaciones de todos"; pasado un rato de lectura se hicieron varias interrupciones, momentos en los que volvieron a repetirse los repiques, las salvas y el toque de música, el reparto entre el pueblo de "canastos de dulces y monedas de plata y vellón", los vivas y las aclamaciones. Al finalizar, el alcalde devolvió la Constitución a la mesa y corrió el velo del retrato, mientras que por la noche hubo iluminación completa. A partir del día 3 comenzaron los "regocijos públicos de novillos y otros festejos de alegria, con el mejor orden", hasta el día 6 inclusive. El juramento, celebrado el día 8 en la iglesia parroquial, estuvo precedido de nuevo de los habituales repiques de campana, iluminación completa y salvas, y finalizó repitiendo la primera de esas acciones; durante su desarrollo se tomaría en varias ocasiones el ejemplar de la Constitución que se encontraba sobre una mesa en el presbiterio y bajo el retrato de Fernando VII67.

El ceremonial celebrado en San Juan del Puerto, villa próxima a la anterior, se celebró en fechas muy próximas a ésta y bajo una parafernalia muy parecida. De hecho, la publicación tuvo lugar el 6 de septiembre sobre un tablado montado para la ocasión, "con todo el ornato que ha sido posible", en cuyo centro, bajo un dosel, se encontraba un retrato de Fernando VII franqueado por dos soldados y cubierto con un velo, el cual se descubrió al inicio del acto, cuando comenzaron los repiques de campana y las salvas de artilleria por parte de la tropa que estaba

65 Por ejemplo, en Almonte, Niebla y La Palma tendrian un papel fundamental los respectivos jueces comisionados que, llegados de fuera, estaban encargados de gestionar la celebración de la publicación y el juramento, e incluso de impulsar la elevación de un nuevo ayuntamiento. ACD, SGE, leg. 25, $\mathrm{n}^{\circ} 1$, docs. 15, 109 y 112 , s.f.

66 En aquellos pueblos que mantuvieron un ritual festivo menos original y ajustado a lo marcado por la normativa solía insistirse en la certificación en el decoro, la alegría y el regocijo demostrados por los asistentes. En líneas generales, así quedaba reflejado en los casos de Huelva -había contado desde julio de 1811 con una Junta de Subsistencia siguiendo el modelo bonapartista, y los actos se programaron para los dias 12 y 13 de septiembre (Archivo Municipal de Huelva, Actas capitulares, leg. 27, fol. 89)-, Palos de la Frontera -18 y 20 de septiembre-, Villarrasa -20 y 27 de septiembre-, Escacena del Campo -10 y 12 de octubre- y Manzanilla - 11 y 12 de octubre-. ACD, SGE, leg. 25, n 1, docs. 114, 170, 67 y 95.

${ }^{67} \mathrm{ACD}$, SGE, leg. 25, $\mathrm{n}^{\circ} 1$, doc. 156, s.f. 
formada delante del mismo tablado. En aquel momento el alcalde, hincando la rodilla, tomó el ejemplar de la Constitución y se lo pasó al regidor decano, quien, "repitiendo el mismo afectuoso y respetuoso ceremonial", daba inicio a su lectura, en la que en algunos momentos de descanso se profirieron salvas y vivas en expresión de "júbilo y alegria". Al finalizar, las autoridades tiraron entre el pueblo "puñados de moneda de plata", así como muchos dulces. El 8 de septiembre tendría lugar el juramento con repiques de campana y salvas de fusilería y en un templo lleno con el vecindario de ambos sexos, a cuya finalización continuaron las muestras de festividad con repiques, salvas y vivas "fervorosos [a] nuestra Nación Española, nuestra deseada y feliz Constitución y nuestro amado Rey el Señor D. Fernando Séptimo"68.

Parte de la escenografia descrita estuvo presente en otros pueblos del entorno en los actos celebrados en las siguientes semanas. En Moguer, ciudad que contó con un acuartelamiento de tropas francesas, la publicación y el juramento tendrian lugar los días 12 y 13 de septiembre. En el primer caso, se adornaron las galerías de las casas consistoriales y delante, en la plaza, se colocó un tablado con cuatro columnas sobre las que ondeaban las banderas de España, Gran Bretaña, Portugal y Rusia, y en su fondo sobre un dosel el retrato de Fernando VII. Al inicio del acto los alcaldes depositaron un ejemplar de la Constitución que portaban en una batea de plata, abriéndose a continuación el repique de campanas y la música de una orquesta que se había preparado para la ocasión, momento en el que se descubría el retrato del rey, todo lo cual "causó tanto júbilo en las gentes de que se hallaba ocupada toda la plaza, ventanas, balcones y calles inmediatas que no se oía más que un conjunto de aclamaciones y vivas". La lectura estuvo entrecortada por los continuos vivas, y a su finalización, además de éstos, comenzaron la música y los repiques hasta el oscurecer, cuando se dio inicio a la iluminación, acompañada de "unos lucidos fuegos artificiales". El juramento, precedido de una misa cantada con música traída al efecto, contó a su conclusión con nuevas muestras de "júbilo y alegría", y en la noche se llevó a cabo la iluminación "que aún excedió a la del anterior, la música en el frente de las casas consistoriales y unos vistosos fuegos artificiales de mano y un castillo". Y los dos siguientes días, como parte de los actos festivos programados, se celebraron dos funciones de misa cantada y sermones: una por haberse publicado la Constitución y "que se digne influir a todos su verdadera observancia", y otra por "las victorias conseguidas por nuestras Armas contra los enemigos" $"$.

En Villalba del Alcor también se adornó la plaza pública con colgaduras y se colocó un retrato de Fernando VII para celebrar el acto de publicación el 27 de septiembre, al que concurrió la mayor parte del vecindario "y aún de los pueblos inmediatos", y que recibió la Constitución "con el mayor aplauso y vivas" en muestra del "júbilo y entusiasmo que reinaba en sus corazones". El juramento se efectuó el día 29, concluyéndose el mismo con salvas de escopetas y algunos cohetes ${ }^{70}$.

En Almonte la publicación se efectuaba el 1 de octubre en la plaza pública y concurrió en gran número "toda clase de persona" que formaba parte del pueblo,

\footnotetext{
68 ACD, SGE, leg. 25, $\mathrm{n}^{\circ} 1$, doc. 142, s.f.

$69 \mathrm{ACD}, \mathrm{SGE}$, leg. $25, \mathrm{n}^{\circ} 1$, doc. 103 , s.f.

70 ACD, SGE, leg. 25, $n^{\circ} 1$, doc. 163, s.f.
} 
para lo cual se había montado un "magnífico tablado" y adornado la fachada de las casas consistoriales "con paños de corte y colgaduras especiales" y puesto un "hermoso dosel", en cuya parte superior se colocó además un retrato de Fernando VII. En cuanto al juramento, se llevó a cabo el 4 de ese mismo mes "hallándose en todo el acto S. M. manifiesto", y donde se había puesto en el presbiterio un altar portátil con dos atrileras de plata con cuanta "decencia fue posible", colocando una insignia de la santa cruz en el medio, en una de ellas un libro de los santos evangelios y en otra un ejemplar de la Constitución. Al finalizar la misa, en juez interino puso sus manos sobre ambos volúmenes y recibió el juramento del pueblo y el clero ${ }^{71}$.

En algún pueblo cercano a Almonte y cuyos actos se celebraron en fechas próximas a lo experimentado en aquel, también es posible identificar un ritual muy parecido al practicado en ese enclave, y no solo en lo referente a los aspectos generales marcados por la normativa. Así, en Bollullos Par del Condado, recién instalado el nuevo ayuntamiento constitucional, la publicación se desarrolló el 3 de octubre con adornos y ante el retrato de Fernando VII, mientras que el juramento se efectuó el día 11 ante un altar formado por "la insignia de una Santa Cruz, el libro de los Evangelios y un exemplar de la Constitución"72.

En otros pueblos también es posible identificar por aquellas mismas fechas algunos elementos que resultaban ya conocidos. En La Palma del Condado en lo que respecta a la presencia del retrato del monarca y a la parafernalia que lo envolvia, y en cuyo juramento, celebrado el día 4 de octubre, se entonó el tedeum "con copiosas lágrimas de gozo y alegría de los asistentes que en gran número se hallaban reunidos en el Santo templo por ver ya restaurada la libertad tan deseada, y que tanto había oprimido el Govierno intruso"73. Y en Hinojos las referencias compartidas fuera de normativa quedaban circunscritas principalmente a la simbología ocupada en el juramento, la cual resultaba claramente impregnada de significados y adscripciones religiosas propias del marco en el que aquel se desarrollaba: ante un altar portátil situado en el presbiterio, con el libro de los Santos Evangelios en una atrilera y la Constitución en otra, y en medio una insignia de la Santa Cruz, practicándose a su finalización una procesión "intra claustro con S.M. manifiesto para mayor solemnidad del acto"74.

En otros casos de aquel mismo mes el componente religioso también cobraba una especial resonancia, acompañado además por otras acciones que venían a reforzar los lazos dentro de la propia comunidad local. En Bonares, tras la publicación ejecutada el 10 de octubre, se llegó a tirar "dinero y dulces a los concurrentes". Y una vez efectuado el juramento al siguiente dia se programaron tres "solemnísimas funciones" de Iglesia, la primera dedicada a la festividad del dia, la segunda a Santa Maria Salomé, patrona de la villa, y la tercera a San Francisco de Borja, patrón de la misma; asimismo, se hicieron unas honras de campaña por todos los muertos en la guerra, "todas con el aparato más pomposo, de oradores,

71 ACD, SGE, leg. 25, $\mathrm{n}^{\circ} 1$, doc. 15, s.f.

72 ACD, SGE, leg. 25, no 1, doc. 25, s.f.

73 La publicación tuvo lugar el 2 de octubre. ACD, SGE, leg. 25, nº 1, doc. 112, s.f.

74 La publicación y el juramento se realizaron el 7 y el 18 de octubre respectivamente. ACD, SGE, leg. 25, $\mathrm{n}^{\circ} 1$, doc. 84, s.f. 
fuegos, luminarias y regocijos" en la plaza, "teniendo a la vista con toda magnitud y decencia a nuestro mui amado y legítimo Rey D. Fernando Séptimo"75.

Y en Niebla, el principal enclave de la ocupación francesa en la región, en muestra de la "alegría y contento por verse libres de una tirania y gobernados por unas leyes tan sabias como christianas", el 17 de octubre se publicó la Constitución en la plaza, en la que se había dispuesto un tablado con el retrato de Fernando VII, a cuya finalización, "y en su regocijo", además de vivas y aclamaciones y un repique general de campanas, se arrojaría en la propia plaza "por sus ventanas porción de dulces al suelo", mientras que en la casas capitulares continuaron las muestras de regocijo, con un convite general de dulces y bebidas, "sin dejarse ver otra cosa que alegría general en todos", continuándose en la noche con iluminación general, repiques, vivas y aclamaciones, cohetes y tiros de fusil o escopeta. En la tarde del siguiente dia, el domingo 18, una vez hecho el juramento, se hizo una procesión solemne por el pueblo a la Santísima Virgen del Pino, y en la noche repiques de campana, candelas y un castillo de fuegos de gran altura y otros cuatro más pequeños. Al siguiente día, el lunes 19, se celebraron en la parroquia unas solemnes honras "por las almas de todos los que han muerto en la Guerra por la defensa de la Nación y sus derechos"76.

En definitiva, ya fuese de una manera más o menos compleja, con añadidos o sin ellos, lo cierto es que las muestras de júbilo y alegría de la población se canalizaron a partir de mecanismos y universos simbólicos de largo recorrido y que, como tal, resultaban conocidos y compartidos por todos, y en los que se combinaron elementos generales según quedaban establecidos por la normativa al uso, con otros particulares como resultado de la lectura, interpretación y programación que cada uno de ellos hacía.

\section{CONSIDERACIONES FINALES}

Independientemente de las similitudes de los actos celebrados en los distintos pueblos del suroeste, o de los perfiles diferentes y concretos que alcanzarian en cada uno de estos -y que debieron de estar conectados asimismo con realidades y tradiciones propias-, en todos los casos se mezclaban y solapaban, aunque con distinto grado, la celebración por la Constitución con la festividad por la victoria de la causa fernandina. A partir de los casos analizados se puede sostener que en aquellos enclaves que participaron de forma más clara en el engranaje politico-institucional instaurado por los franceses el ritual festivo llegó a resultar más rico e intenso, posiblemente por la necesidad que tenían de manifestar sin ambages su clara vinculación con el régimen traído por los ahora vencedores; mientras que en aquellos que de manera más o menos constante se mantuvieron dentro de la órbita de los poderes gaditanos el ceremonial resultó más modesto y sencillo, por cuanto no constituía una muestra de adhesión de carácter general, sino una manifestación, sino una manifestación concreta en torno al texto promulgado en Cádiz.

\footnotetext{
75 ACD, SGE, leg. 25, $\mathrm{n}^{\circ} 1$, doc. 26, s.f.

76 ACD, SGE, leg. 25, no 1 , doc. 109, s.f.
} 
La publicación y el juramento constitucional, cuya iniciativa y formato vinieron marcados desde fuera de la comunidad local, no encontrarian sin embargo sus contornos definitivos sino a partir de otros elementos y lecturas trazados en clave interna. Así, por ejemplo, no resultó inusual aderezar los actos cuyo protagonismo recaía en las autoridades civiles con la imagen de Fernando VII, que vendría a materializar y simbolizar a ojos de todos los concurrentes no solo la lucha más general frente al enemigo francés y la dinastía Bonaparte, sino también el final de la ocupación y los padecimientos concretos que habían sufrido desde la llegada de las fuerzas y autoridades josefinas. De la misma forma, aquellos otros que se celebraban en la iglesia y en los que tenían un papel significativo los miembros del clero también se complementaban en ocasiones con procesiones o actos religiosos que venían a representar para los participantes tanto el triunfo general ante los enemigos de la religión católica como el destacado protagonismo que en aquella victoria habian tenido los santos patronos del pueblo, contribuyendo así a afianzar además los lazos simbólicos e identitarios de la comunidad local. Esto último se vería reforzado asimismo con aquellas acciones festivas y convites en los que participaron buena parte del vecindario $y$ en los que, a pesar de que cada grupo podía asumir roles $y$ protagonismos diferentes, en conjunto no hacian sino sustentar una idea de comunidad integrada e integradora, que reconocía sus diferencias internas pero también sus valores e intereses compartidos.

En definitiva, aunque no parece posible trazar un relato cerrado y definitivo a partir de los diferentes casos analizados, lo que sí quedan esbozados son algunas de las líneas de desarrollo y aplicación concretas que lo caracterizan. La conjugación de diferentes variables en torno al tiempo, el espacio y el ritual simbólico, además de presentarse como un marco adecuado para valorar las distintas experiencias a nivel municipal, proporciona asimismo algunas claves de interpretación respecto a las diferentes lecturas y proyecciones que alcanzaban al interior de la comunidad local dentro de un marco general definido por la politización y la densificación del espacio público. No es poco lo que ello representaría en el conjunto de aquellos años, como tampoco lo sería para buena parte de la contemporaneidad.

Enviado el (Submission Date): 07/12/2020

Aceptado el (Acceptance Date): 03/02/2021 